\section{FIRST RECORD OF SCOPOLI'S SHEARWATER Calonectris diomedea IN SLOVENIA}

\section{Prvo opazovanje rumenokljunega viharnika Calonectris diomedea v Sloveniji}

\section{JURIJ HANŽEL}

Židovska ulica 1, SI-1000 Ljubljana, Slovenia, e-mail: jurij. hanzel@gmail.com

Scopoli's Shearwater Calonectris diomedea breeds in the Mediterranean (BIRDLIFE INTERNATIONAL 2016A), with isolated cases of breeding recorded on the French Atlantic coast (MAYs et al. 2006). Following a recent reassessment at its largest colony (Zembra Island, Tunisia), the global population is estimated at 141,000-223,000 breeding pairs (Defos DU RAU et al. 2015, BIRDLIFE INTERNATIONAL 2016A). Based on limited data, the population appears to be in slight decline, $2 \%$ over three generations, but is still evaluated as "Least Concern" (CARBoneras et al. 2013, BirdLife InTERNATIONAL 2016A). The majority of the population leaves the Mediterranean to winter in the
Atlantic Ocean, mainly in three areas: the Benguela and Agulhas Currents, the Brazilian Current and the Canary Current (Ristow et al. 2000, CAMPHUYSEN \& VAN DER MEer 200I, GonZÁlez-Solís et al. 2007, PÉron et al. 2012). The autumn passage to the Atlantic takes place between mid-October and late-November, spring passage in the reverse direction between late February and early April (RAmos et al. 2009).

Until recently Scopoli's Shearwater, first described by Joannes Antonius Scopoli in 1769, was considered the nominotypical subspecies of the polytypic Cory's Shearwater, together with Calonectris (diomedea) borealis which breeds mainly in the Atlantic Ocean. Field characters to differentiate the two subspecies were described by GuTIÉRREZ (1998) and the split first proposed by SANGSTER et al. (1999) based on differences in molecular data, morphology and vocalization. The decision was not universally accepted at the time, but is now more widely adopted (SANGSTER et al. 20I2, BirdLIFE INTERNATIONAL 20I6A).

Because Scopoli was based in Carniola for a significant part of his professional life, his species descriptions are of particular interest for Slovenian ornithologists. The species is named Procellaria diomedea (SCOPOLI 1769) and Scopoli refers to Linnaeus's "Diomedea (exulans)" (Linnaeus 1766) and Jonston's "Diomedea" (Jonstonus 1650). He proceeds to briefly describe the species without giving

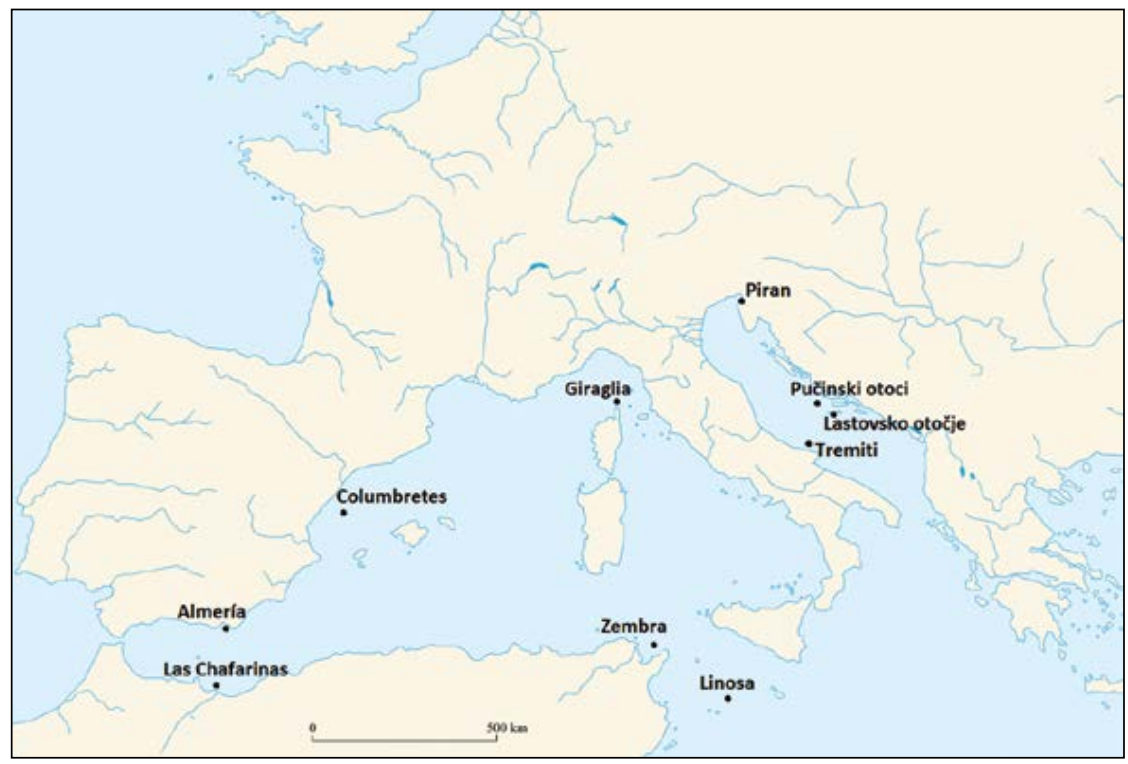

Figure 1: Map of the key sites mentioned in the text (map: Wikimedia Commons under the Creative Commons Licence, annotation: J. Hanžel)

Slika 1: Zemljevid ključnih lokacij, omenjenih v besedilu (zemljevid: Wikimedia Commons, licenca Creative Commons, pripisi: J. Hanžel) 
a type locality and mentions that a specimen is stored in "Museum Turrianum". This account has attracted controversy for several reasons. Firstly, Linnaeus's Diomedea is clearly not a shearwater, as it is described as pelican-sized. This may have been an oversight on Scopoli's part as Linnaeus's work lacks illustrations. Scopoli refers to his bird as crow-sized and refers to plate 46 in Jonston's work, where a shearwater is clearly illustrated. Museum Turrianum was a private collection of Count Thurn, where the specimens bore no mention of their origin and are now widely believed to have been lost (HARTERT 1923, GREGORI 2008). Judging by some other species described from the same collection (e.g. Ring-necked Parakeet Psittacula krameri), not all the specimens were obtained regionally and it is not entirely impossible that Scopoli described a different species of shearwater. Scopoli's description was disputed and later rejected by the British Ornithologists' Union (BOU) (Hartert 1923, British Ornithologists' union 1933). The BOU revoked its initial decision in 1946 and, through a tenuous indirect reference via Jonston to Aldrovandus (I645), determined the type locality as the Tremiti Islands in Italy (Figure 1) (BRITISH ORNITHOLOGISTS' UNION I946) - which were never mentioned by Scopoli, nor did he refer to Aldrovandus in relation to the shearwater despite quoting him elsewhere in his work.

The breeding grounds nearest to Slovenia are in Italy and Croatia. The Italian breeding population is estimated at 13,344-21,873 pairs (DERHÉ 2012), with colonies closest to Slovenia on the Tremiti Islands (BRICCHETTI \& FraCASSO 2003). The Croatian breeding population is estimated at 700-1200 pairs in two SPAs, Lastovsko otočje and Pučinski otoci (Figure 1) (Bioportal 2016). Both the Italian and Croatian colonies are approximately 400 kilometres away from the Slovenian sea. In landlocked central European countries the species was recorded once in Austria (May 1858) (Albegger 20 I 5) and Switzerland (May i 865; two individuals) (Maumary et al. 2007), while a record from the Czech Republic (May 1936) (VAVŘIK 2015) was not identified beyond Scopoli's/ Cory's Shearwater. Birds from Switzerland (July 1931) and southern Germany (June 1933) were identified as Cory's Shearwaters (MAUMARY et al. 2007).

On 16 Jun 2016, I was seawatching in Piran (Northern Adriatic Sea, SW Slovenia) (Figure 1). The weather was mostly cloudy with a south wind of $9 \mathrm{~m} / \mathrm{s}$ and gusts of up to $12 \mathrm{~m} / \mathrm{s}$. At $10.10 \mathrm{hrs}$, I spotted a large shearwater flying towards NNE about $2700 \mathrm{~m}$ offshore. After two minutes of following the bird with my scope a second individual flew into view and both then passed a Yellow-legged Gull Larus michabellis.
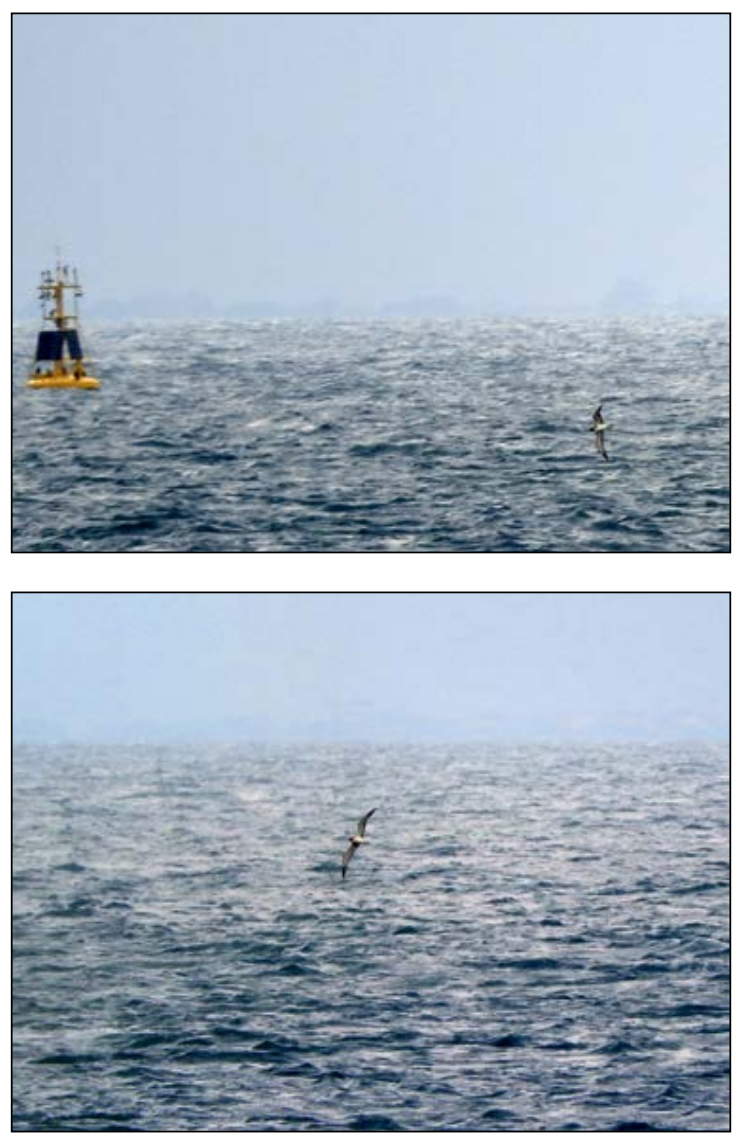

Figure 2: Scopoli's Shearwater Calonectris diomedea, off Piran, 16 Jun 2016. This individual passed closest to shore, approximately $1300 \mathrm{~m}$ from my observation point. Piran's oceanographic buoy is visible in the background. (photo: J. Hanžel)

Slika 2: Rumenokljuni viharnik Calonectris diomedea, Piran, 16. 6. 2016. Ta osebek se je najbolj približal obali, približno 1300 m od opazovalne točke. V ozadju je vidna piranska oceanografska boja. (foto: J. Hanžel)

The birds were also observed by Katarina Benulič and record photographs using a compact Nikon Coolpix P610 compact camera were obtained before the birds were lost from sight after a total observation time of 6 minutes.

In direct comparison with a Yellow-legged Gull, the two shearwaters were only slightly smaller. Their flight was characterized by series of 4-7 flexible wingbeats, interspersed with long glides. The upperparts were brownish-grey with a small white patch on the uppertail of one of the birds. The bill was light-coloured, but no further details were noted at this distance. The underparts were clean white and the underwing had a narrow black border. The exact pattern of the primaries 
was impossible to assess, nor was it visible in the photographs examined later. Based on these characters I immediately identified the birds as Scopoli's/Cory's Shearwaters. During the course of the day I observed seven more Scopoli's/Cory's Shearwaters, the closest of which I managed to photograph (Figure 2). Unfortunately, the primary pattern was impossible to assess with certainty. I saw another bird from the same observation point a day later, on $17 \mathrm{Jun}$. A total of up to 10 different individuals were thus observed.

The record was accepted as the first of Scopoli's Shearwater for Slovenia and added to category A by the Slovenian Rarities Committee (KRED). Despite the inability to identify the birds beyond Scopoli's/ Cory's Shearwater based on presented evidence, the Committee adopted a pragmatic approach outlined below. The Cory's Shearwater is known to breed within the Mediterranean near Almería (GómEz-Díaz et al. 2006, BirdLife InTERnATIONAL 2016B) and on Las Chafarinas (Figure 1) (AFÁn et al. 20I4). These two colonies are estimated to hold up to 100 breeding pairs each. Up to two Cory's Shearwaters have also been found on Columbretes Islands (MARTINEz ABrain $e t$ al. 2002), Giraglia (Thibault \& BRETAGNOLLE 1998) and Linosa (Figure 1) (Lo Valvo \& Massa 1988). No Cory's Shearwaters were ever recorded on the Tremiti or in Croatian colonies. Based on these data, the Committee ruled that it was safe to accept the birds as Scopoli's Shearwaters.

The species has long been expected to appear in Slovenia. Somewhat surprisingly, none had been recorded despite recent systematic boat-based surveys targeting the Mediterranean Shag Phalacrocorax aristotelis desmarestii and cetacean surveys (T. GENOv, U. KocE pers. comm.). The species appears to be a rare guest in the Italian half of the Gulf of Trieste, with recent records from May and October (PAROdi 1999, STANIČ 2014 ). Croatian data suggest that small numbers appear irregularly in the northern Adriatic between May and October and exceptionally during the winter (STIPČEvić \& LUKAČ 200I). The highest daily total from the northern Adriatic is from August 1912 when a raft of 30-40 birds was observed (SCHIEBEL 1914). More recent data obtained by tracking breeders from the Tremiti Islands suggest that the Slovenian sea could be within the range of their foraging trips. Most trips were directed towards the north and the northernmost point reached by birds from the studied sample was off Istria's southern tip (CECERE et al. 2013). Birds are probably more likely to be seen in the Slovenian sea in June, rather than July or August given that foraging trips are generally longer during incubation than during chick-rearing.

\section{Povzetek}

Rumenokljuni viharnik Calonectris diomedea gnezdi v Sredozemlju, nam najbližje kolonije so oddaljene približno $400 \mathrm{~km}$ na Tremitskih otokih v Italiji in južnodalmatinskih otokih $\mathrm{v}$ okolici Visa in Lastova. Vrsta v Sloveniji doslej še ni bila opazovana. Dne 16. in 17. 6. 2016 sem na morju pred Piranom s kopnega opazoval do 10 različnih rumenokljunih viharnikov. Zaradi velike oddaljenosti nedvomno razlikovanje od atlantskega rumenokljunega viharnika Calonectris borealis ni bilo mogoče. Nacionalna komisija za redkosti (KRED) je opazovanje kljub temu potrdila kot prvi podatek za Slovenijo (kategorija A). Atlantski rumenokljuni viharniki so v Sredozemskem morju namreč izjemno redki, tako da je mogoče z veliko mero gotovosti zaključiti, da so bile opazovane ptice rumenokljuni viharniki. V severnem Jadranu se pojavljajo predvsem med majem in oktobrom, podatki iz italijanskih kolonij pa kažejo, da tamkajšnji gnezdilci junija dosežejo južne obale Istre.

\section{References}

Afán I., Navarro J., Cardador L., Ramírez F., Kato A., Rodríguez B., Ropert-Coudert Y., Forero M. G. (2014): Foraging movements and habitat niche of two closely related seabirds breeding in sympatry. - Marine Biology 161: 657-668.

Albegger E. (201 5): Sepiasturmtaucher Calonectris diomedea. p. 231. In: Albegger E., Samwald O., Pfeifhofer H. W., Zinko S., Ringert J., Kolleritsch P., Tiefenbach M., Neger C., Feldner J., Brandner J., Samwald F., Stani W. (eds.): Avifauna Steiermark - Die Vögel der Steiermark. BirdLife Österreich - Landesgruppe Steiermark, Leykam Buchverlags Ges. m. b. H. Nfg. \& Co. KG, Graz.

Aldrovandus U. (1645): Ornithologiae tomus tertius ac postremus. - M. Antonii Berniae Bibliopol., Bononia (Bologna).

Bioportal (20I6): Bioportal - web portal informacijskog sustava zaštite prirode. - [http://www.bioportal.hr/gis/], 16/12/2016.

BirdLife InTERnAtional (2016A): Species factsheet: Calonectris diomedea. - [http://datazone.birdlife.org/ species/factsheet/45061132], 15/12/2016.

Birdife International (2016B): Important Bird Areas factsheet: Littoral islets of Murcia and Almería. - [http:// datazone.birdlife.org/site/factsheet/littoral-isletsof-murcia-and-almer\%C3\%ADa-iba-spain/details], 17/12/2016.

Bricchetti P., Fracasso G. (2003): Ornitologia italiana. Vol. 1 - Gavidae-Falconidae. - Alberto Perdisa Editore, Bologna.

British Ornithologists' UnION (1933): Ninth report of the committee on the nomenclature and records of the occurrences of rare birds in the British Islands and on certain necessary changes in the nomenclature of the B. O. U. list of birds. - Ibis 75 (2): 343-351. 
BRITISH ORNITHOLOGISTS' UNION (1946): Seventeenth report of the committee on the nomenclature and records of the occurrences of rare birds in the British Islands and on certain necessary changes in the nomenclature of the B. O. U. list of birds. - Ibis 88 (4): 533-534.

Camphuysen C. J., van Der Meer J. (200I): Pelagic distribution, moult and (sub-)specific status of Cory's Shearwaters Calonectris [d.] diomedea/borealis wintering off South Africa. - Marine Ornithology 29: 89-96.

Carboneras C., Derhé M., Ramírez I. (2013): Update on the population status and dsitribution of Mediterranean Shearwaters. - Report to the Seventh Meeting of the ACAP Advisory Committee, La Rochelle.

Cecere J. G., Catoni C., Maggini I., Imperio S., Gaibani G. (2013): Movement patterns and habitat use during incubation and chick-rearing of Cory's shearwaters (Calonectris diomedea diomedea) (Aves: Vertebrata) from Central Mediterranean: influence of seascape and breeding stage. - Italian Journal of Zoology 80: 82-89.

Defos du Rau P., Bourgeois K., Thévenet M., Ruffino L., Dromzée S., Ouni R., Abiadh A., Estève R., Durand J. P., Anselme L., Faggio G., Yahya J. M., Rguibi H., Renda M., Miladi B., Hamrouni H., Alilech S., Nefla A., JaOuAdi W., Agrebi S., Renou S. (2015): Reassessment of the size of the Scopoli's Shearwater population at its main breeding site resulted in a tenfold increase: implications for the species conservation. - Journal of Ornithology 156: 877-892.

Derhé M. (2012): Developing a Population Assessment for Scopoli's and Cory's Shearwaters Calonectris diomedeal Calonectris borealis. pp. 29-38. In: YésOU P., BACCETTI N., Sultana J. (eds.): Ecology and Conservation of Mediterranean Seabirds and other bird species under the Barcelona Convention - Proceedings of the 13th Medmaravis Pan-Mediterranean Symposium. Alghero (Sardinia) 14-17 Oct 2011. - Medmaravis, Alghero.

Gómez-Díaz E., González-Solís J., Peinado M. A., Page R. D. M. (2006): Phylogeography of the Calonectris shearwaters using molecular and morphometric data. Molecular phylogenetics and evolution 41: 322-332.

González-Solís J., Croxall J. P., Oro D., Ruiz X. (2007): Trans-equatorial migration and mixing in the wintering areas of a pelagic seabird. - Frontiers in Ecology and the Environment 5 (6): 297-301.

Gregori J. (2008): Joannes A. Scopoli, njegovi “Descriptiones avium (1769)“ in kranjska imena ptičev. - Scopolia 65: 1-32.

GuTIÉRreZ R. (1998): Flight identification of Cory's and Scopoli's Shearwaters. - Dutch Birding 20: 216-225.

HARTERT E. (1923): Die Vögel der paläarktischen Fauna Nachtrag I. - Friedländer \& Sohn, Berlin.

JonstonUS J. (1650): Historiae naturalis de avibus cum aeneis figuris. - Matthaei Meriani, Francofvrti ad Moenvm (Frankfurt am Main).

LinNAEus C. (1766): Systema naturæ per regna tria naturæ, secundum classes, ordines, genera, species, cum characteribus, differentiis, synonymis, locis. Tomus I. Editio duodecima, reformata. - Holmiae (Stockholm).

Lo Valvo M., Massa B. (1988): Considerations on a specimen of Cory's Shearwater ringed at Selvagem Grande and recovered in the Central Mediterranean. - Bocagiana 124: $1-5$.
Martinez-Abrain A., SANChez A., Oro D. (2002): Atlantic Cory's Shearwaters breeding in a colony of Mediterranean Cory's Shearwaters. - Waterbirds 25 (2): 221-224.

Maumary L., Vallotton L., KNaus P. (2007): Die Vögel der Schweiz. -Schweizerische Vogelwarte, Sempach \& Nos Oiseaux, Montmollin.

Mays G., Durand J. M., Gomez G. (2006): Première nidification du Puffin cendré (Calonectris diomedea) sur la façade atlantique française. - Ornithos 13: 316-319. (in French)

Parodi R. (1999): Gli uccelli della provincia di Gorizia. Edizione del Museo Friulano di Storia Naturale 42. Museo Friulano di Storia Naturale, Udine.

Péron C., Grémillet D., Culioli J-M., Faggio G., Gillet P., Mante A., Vidal P. (2012): Exploring marine habitats of two shearwater species breeding on French Mediterranean islands to identify Marine Protected Areas. pp.19-25. In: Yésou P., Baccetti N., Sultana J. (eds.): Ecology and Conservation of Mediterranean Seabirds and other bird species under the Barcelona Convention - Proceedings of the 13th Medmaravis Pan-Mediterranean Symposium. Alghero (Sardinia) 14-17 Oct 2011. - Medmaravis, Alghero.

Ramos R., Militão T., GonzÁlez-Solís J., Ruiz X. (2009): Moulting strategies of long-distance migratory seabird, the Mediterranean Cory's Shearwater Calonectris diomedea diomedea. - Ibis 151: 151-159.

Ristow D., Berthold P., Hashmi D., Querner U. (2000): Satellite tracking of Cory's Shearwater migration. Condor 102: 696-699.

Sangster G., Hazevoet C. J., van den Berg A. B., RoselaAr C. S., SLuYs R. (1999): Dutch Avifaunal List: species concepts, taxonomic instability, and taxonomic changes in 1977-1998. - Ardea 87 (1): 139-166.

Sangster G., Collinson J. M., Crochet P. A., Knox A. G., Parkin D. T., Votier S. C. (20I2): Taxonomic recommendations for British birds: eighth report. -Ibis 154: 874-883.

Schiebel G. (I914): Über die Vögel der Insel Arbe, II. Teil: Ein Sommeraufenthalt im Jahre 1912. - Ornithologisches Jahresbericht 24: 16-27.

Scopoli J. A. (1769): Annus I. historico-naturalis. Descriptiones avium. - Christ. Gottlob Hilscheri, Lipsiae (Leipzig).

STANIČ D. (20 I 4): Cory's Shearwater Calonectris diomedea. Acrocephalus 35 (162/163): 181-182.

STIPČEviĆ M., LUKAČ G. (200I): Status of tubenose seabirds Procellariiformes breeding in the eastern Adriatic. Acrocephalus 22 (104/105): 9-21.

Thibault J.-C., Bretagnolle V. (1998): A Mediterranean breeding colony of Cory's Shearwater Calonectris diomedea in which individuals show behavioural and biometric characters of the Atlantic subspecies. - Ibis 140: 522-527.

VAVŘIK M. (20I 5): Seznam ptáků České republiky. - [http:// fkcso.cz/cz-list.htm], 15/12/2016.

Prispelo / Arrived: 18. 12. 2016

Sprejeto / Accepted: 18. 1.2017 